\title{
Recent exploration of bioactive pigments from marine bacteria
}

\author{
Tatas Hardo Panintingjati Brotosudarmo ${ }^{\mathrm{a}, *}$, Leenawaty Limantara ${ }^{\mathrm{b}}$, Delianis Pringgenies ${ }^{\mathrm{c}}$ \\ a Ma Chung Research Center for Photosynthetic Pigments (MRCPP) and Department of Chemistry, \\ Universitas Ma Chung, Malang 65151 Indonesia \\ b Center for Urban Studies, Universitas Pembangunan Jaya, South Tangerang 15413 Banten, Indonesia \\ c Department of Marine Science, Faculty of Fisheries and Marine Science, Universitas Diponegoro, \\ Semarang, Jawa Tengah 50275 Indonesia
}

*Corresponding author, e-mail: tatas.brotosudarmo@machung.ac.id

Received 3 May 2021

Accepted 10 May 2021

\begin{abstract}
Microbial pigments of marine origin are gaining increasing attention in current research due to their widely perceived applications as natural food colorants, antioxidants, antimicrobial compounds, anticancer agents, and immune stimulators. This review is a short acknowledgement of the significant progress achieved over the past five years of studies on pigments from marine bacterial isolates. Herein, we also discuss the typical challenges, as well as recent technical developments, in isolating and cultivating marine bacteria and in conducting determination of pigments as critical considerations in doing research in this field.
\end{abstract}

KEYWORDS: bioactive pigments, combinatorial approaches, culture cultivation, genome mining, marine bacteria

\section{INTRODUCTION}

Marine microorganisms, due to their rich biodiversity and genetic capacity, represent a significant source of natural product discovery [1], with success rates up to 4 times higher than other naturally derived compounds [2]. In common microbial cultures, such as marine agar, seawater-based rich media agar, and Zobell agar medium, several marine gram-positive and gram-negative bacteria appear to produce an array of pigments [3], such as carotenes (yellow to red), prodiginines (red), phenazines (yellow crystalline, deep-red solution in sulfuric acid), quinones (bright yellow), and violacein (purple). These marine bacterial pigments are being explored for their production, which is clinically and industrially important because they have demonstrated various biological activities, such as antioxidant, antimicrobial, and anticancer, as well as acting to stimulate immunity [4].

In the 1960s, research on natural marine products began to flourish [5], primarily due to advances in instrumentation for structure elucidation, particularly the mass spectrometry, and isolation techniques as well as the availability of scuba gear for the collection of marine organisms at certain depths. Highlights of achievements have been frequently reviewed and indicate the structural complexity and

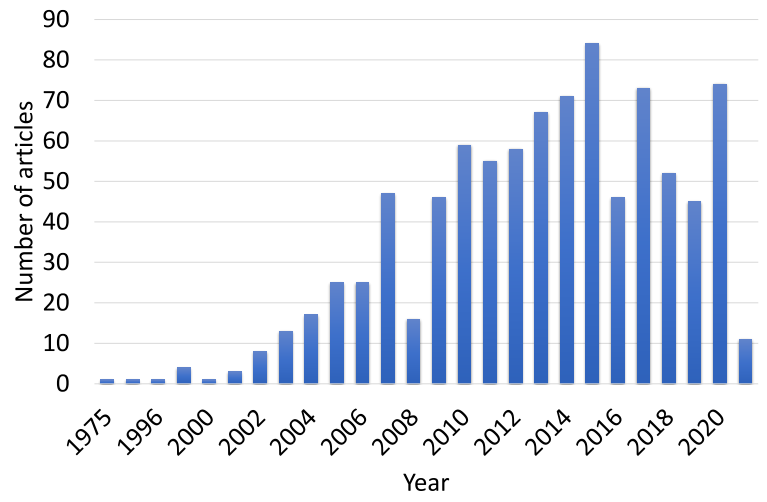

Fig. 1 Search results using the keyword "novel pigment; marine bacteria" in the search engine provided by https:// pubmed.ncbi.nlm.nih.gov/ from 1975 to 2021 for journal articles.

potent biological activities of these pigments. In the PubMed search engine, using the keyword "novel pigments; marine bacteria", the number of articles reporting on bacterial marine pigments increased from only 8 articles in 2002 to 84 articles by 2015 (Fig. 1). These articles include research on the isolation and determination of new compounds and on new bacterial species or strains, research on bioactivity assays and therapeutic studies of pigments, and review articles. The number of pub- 
lished articles on marine bacterial pigments has shown a rather downhill trend since 2015, despite the untapped potential of marine biodiversity.

\section{HIGHLIGHTS DURING THE PAST FIVE YEARS}

The most recent pigments that were extracted from marine bacterial isolates that have been characterized in the past five years are listed in Table 1. At least 17 species have been successfully isolated from their native habitat, including in seawater, sediments, and in association or affiliation with marine invertebrates. It has been extensively reviewed that marine sediment holds untapped potential for novel taxonomic and bioactive bacterial diversity comparable to seawater [6], in which both aerobic and anaerobic microbial ecosystems exist that persist on very low fluxes of bioavailable energy over geologic time [7]. It was reported that seawater and sediments comprise a similar number of distinct bacterial species with a mean \pm standard deviation (SD) of $1378 \pm 61$ species for seawater and $1452 \pm 74$ species for sediments [6]. Living together and using invertebrates as hosts and microorganisms as symbionts is also common in marine environments [8]. Marine invertebrates, particularly sessile invertebrates, often rely upon chemical defence, and symbiosis with biochemically versatile microorganisms is an efficient strategy for survival [9]. In the absence of their microbial symbionts, most marine invertebrates cannot survive $[10,11]$. Microbial symbionts have been shown to produce a variety of tailored biochemical traits due to coevolution with their specific host, making them a rich source of secondary metabolites, particularly pigments with medically and commercially attractive bioactivities [12-14].

Several new and rare compounds have been characterized over the past five years (Table 1). Carotenoids are a family of yellow to orange-red pigments, generally comprising a 40-carbon skeleton composed of 8-isoprene units. In carotenoid groups, seven rare compounds include the $\mathrm{C}_{45}$ and $\mathrm{C}_{50}$ carotenoids. By 2017, more than 250 carotenoids of marine origin had been identified [15], and the unique compositions present in marine microorganisms have promoted the use of carotenoids as a chemical signature for rapid chemotaxonomic profiling. Six new and rare carotenoids that have been reported in the past five years include $2^{\prime}$ isopentenyldehydrosaproxanthin $\left(\mathrm{C}_{45}\right.$ carotenoid $)$ from Arthrobacter sp. P40 [16], decaprenoxanthin and its glucosylated derivatives $\left(\mathrm{C}_{50}\right.$ carotenoids) from Rhodopirellula rubra $\mathrm{LF}^{\mathrm{T}}$ [17], and zeaxanthin sulfate from Erythrobacter flavus KJ5 [18]. Newly identified marine bacteria that produce high levels of astaxanthin and its derivatives, such as $2^{\prime}$-hydroxyastaxanthin and $2,2^{\prime}$-dihydroxyastaxanthin, have also been reported $[19,20]$. The unique structure of astaxanthin, which contains both a keto group and hydroxyls, plays an important role in neutralizing reactive oxygen species (ROS) [21].

Newly characterized bioactive pigments from the quinone group have also been reported, such as fridamycins $\mathrm{H}$ and fridamycins I from Actinokineospora spheciospongiae sp. nov., along with three known compounds, actinosporins C, D, and $G$ [22]. Mersaquinone, a new tetracene derivative that exhibits antibacterial activity against methicillin-resistant Staphylococcus aureus, was successfully characterized and reported [23]. In addition, two new polycyclic anthraquinones, Nacetyl-N demethyl-mayamycin and Streptoanthraquinone A, were found in Streptomyces sp. 182SMLY, which were successfully isolated from a sample of marine sediment at a $3.6 \mathrm{~m}$ depth [24]. Although prodiginines were initially identified from the terrestrial bacterium Serrantia marcescens, these compounds were subsequently obtained from several bacteria in different marine habitats, such as Pseudomonas rubra strains PS1 and SB14, which were isolated from seawater [25], and Zooshikella sp. and Streptomyces sp. that were isolated from sediment [26]. Phenazine pigments, including phenazine-1-carboxylic acid and pyocyanin, were successfully characterized from Pseudomonas aeruginosa isolated from sediment $[27,28]$. New Pseudoalteromonas byunsanensis strains JW1T and JW3 isolated from surface seawater were found to produce violacein [29].

\section{MAIN CHALLENGES}

The low percentage of microbes that can be readily cultured and sustainably grown under laboratory conditions is one of the primary hurdles to continued characterization of bioactive pigments. In fact, more than $99 \%$ of marine microorganisms have not been successfully cultured under laboratory conditions [30]. Approximately 107 types of bacteria were isolated from one gram of sediment, and only $5 \%$ of those microorganisms were able to be grown in the lab [31]. This phenomenon is referred to as the "great plate count anomaly" [32], a term to describe differences in the order of magnitude 
Table 1 Most recent bio-pigments extracted from marine bacterial isolates have been characterized in the last five years.

\begin{tabular}{|c|c|c|c|c|c|c|}
\hline Pigment & $\begin{array}{l}\text { Chemical } \\
\text { Formula }\end{array}$ & $\begin{array}{l}\lambda_{\max } \\
(\mathrm{nm})\end{array}$ & $\begin{array}{l}\text { Molecular } \\
\text { ion }(\mathrm{m} / \mathrm{z})\end{array}$ & $\begin{array}{l}\text { Marine bacterial } \\
\text { species }\end{array}$ & $\begin{array}{l}\text { Therapeutic } \\
\text { application }\end{array}$ & Ref. \\
\hline \multicolumn{7}{|l|}{ Carotenoid group } \\
\hline Decaprenoxanthin & $\mathrm{C}_{50} \mathrm{H}_{72} \mathrm{O}_{2}$ & $417,442,471$ & $705.6[\mathrm{M}+\mathrm{H}]^{+}$ & Arthrobacter sp. P40 & Antioxidant & {$[17]$} \\
\hline $\begin{array}{l}\text { Decaprenoxanthin } \\
\text { monoglucoside }\end{array}$ & $\mathrm{C}_{56} \mathrm{H}_{82} \mathrm{O}_{7}$ & $417,442,471$ & $867.6[\mathrm{M}+\mathrm{H}]^{+}$ & Arthrobacter sp. P40 & Antioxidant & {$[17]$} \\
\hline $\begin{array}{l}\text { Decaprenoxanthin } \\
\text { diglucoside }\end{array}$ & $\mathrm{C}_{62} \mathrm{H}_{92} \mathrm{O}_{12}$ & $417,442,471$ & $1029.6[\mathrm{M}+\mathrm{H}]^{+}$ & Arthrobacter sp. P40 & Antioxidant & {$[17]$} \\
\hline $\begin{array}{l}2^{\prime} \text {-Hydroxy- } \\
\text { astaxanthin }\end{array}$ & $\mathrm{C}_{40} \mathrm{H}_{52} \mathrm{O}_{5}$ & 478 & $613[\mathrm{M}+\mathrm{H}]^{+}$ & Brevundimonas sp. strain N-5 & Antioxidant & {$[19]$} \\
\hline $\begin{array}{l}2,2^{\prime} \text {-Dihydroxy- } \\
\text { astaxanthin }\end{array}$ & $\mathrm{C}_{40} \mathrm{H}_{52} \mathrm{O}_{6}$ & 478 & $629.0[\mathrm{M}+\mathrm{H}]^{+}$ & $\begin{array}{l}\text { Brevundimonas scallop } \\
\text { Brevundimonas sp. strain N-5 }\end{array}$ & Antioxidant & {$[19,20]$} \\
\hline Dehydroflexixanthin & $\mathrm{C}_{40} \mathrm{H}_{52} \mathrm{O}_{3}$ & - & $581[\mathrm{M}+\mathrm{H}]^{+}$ & Rhodopirellula rubra $\mathrm{LF}^{\mathrm{T}}$ & Antioxidant & {$[16]$} \\
\hline $\begin{array}{l}\text { 2'-Isopentenyldehy- } \\
\text { drosaproxanthin }\end{array}$ & $\mathrm{C}_{45} \mathrm{H}_{64} \mathrm{O}_{2}$ & 470,500 & $637[\mathrm{M}+\mathrm{H}]^{+}$ & Rhodopirellula rubra $\mathrm{LF}^{\mathrm{T}}$ & Antioxidant & {$[16]$} \\
\hline Saproxanthin & $\mathrm{C}_{40} \mathrm{H}_{56} \mathrm{O}_{2}$ & $444,470,500$ & $590[\mathrm{M}+\mathrm{Na}]^{+}$ & $\begin{array}{l}\text { Rhodopirellula rubra } \mathrm{LF}^{\mathrm{T}} \\
\text { Rubinisphaera brasiliensis } \mathrm{Gr} 7\end{array}$ & Antioxidant & {$[16]$} \\
\hline Zeaxanthin-sulfate & $\mathrm{C}_{40} \mathrm{H}_{55} \mathrm{SO}_{5} \mathrm{Na}$ & $427,453,481$ & $648.5[\mathrm{M}-\mathrm{Na}]^{-}$ & Erythrobacter flavus KJ5 & Antioxidant & {$[18,41]$} \\
\hline \multicolumn{7}{|l|}{ Quinone group } \\
\hline Bisantraquinone 1 & $\mathrm{C}_{32} \mathrm{H}_{25} \mathrm{O}_{9}$ & $\begin{array}{l}229,261,287 \\
361,415\end{array}$ & $553.15[\mathrm{M}+\mathrm{H}]^{+}$ & Ecteinascidia turbinada & $\begin{array}{l}\text { Antibacterial } \\
\text { Anticancer }\end{array}$ & {$[44]$} \\
\hline Fridamycins $\mathrm{H}$ & $\mathrm{C}_{25} \mathrm{H}_{26} \mathrm{O}_{11}$ & $231,253,293$ & $503.15[\mathrm{M}+\mathrm{H}]^{+}$ & $\begin{array}{l}\text { Actinokineospora spheciospon- } \\
\text { giae sp. nov. }\end{array}$ & Antitrypanosomal & {$[22]$} \\
\hline Fridamycins I & $\mathrm{C}_{32} \mathrm{H}_{33} \mathrm{NO}_{10} \mathrm{Na}$ & $232,253,294$ & $614[\mathrm{M}+\mathrm{H}]^{+}$ & $\begin{array}{l}\text { Actinokineospora spheciospon- } \\
\text { giae sp. nov. }\end{array}$ & \multicolumn{2}{|l|}{ Antitrypanosomal } \\
\hline $\begin{array}{l}\text { N-acetyl-N demethyl- } \\
\text { mayamycin }\end{array}$ & $\mathrm{C}_{27} \mathrm{H}_{25} \mathrm{NO}_{8}$ & 328,443 & $514.15[\mathrm{M}+\mathrm{Na}]^{+}$ & Streptomyces sp. 182SMLY & Antibacteria & {$[24]$} \\
\hline Mersaquinone & $\mathrm{C}_{19} \mathrm{H}_{12} \mathrm{O}_{6}$ & $\begin{array}{l}218,277,308 \\
350,480,515 \\
550\end{array}$ & $337.07[\mathrm{M}+\mathrm{H}]^{+}$ & Streptomyces sp. & Antibacterial & {$[23]$} \\
\hline $\begin{array}{l}\text { Streptoanthra- } \\
\text { quinone A }\end{array}$ & $\mathrm{C}_{28} \mathrm{H}_{22} \mathrm{O}_{8}$ & $220,330,445$ & $509.12[\mathrm{M}+\mathrm{Na}]^{+}$ & Streptomyces sp. 182SMLY & Antibacterial & {$[24]$} \\
\hline $\begin{array}{l}\text { Prodigiosin group } \\
\text { Prodigiosin }\end{array}$ & $\mathrm{C}_{20} \mathrm{H}_{25} \mathrm{~N}_{3} \mathrm{O}$ & 537 & $324.4[\mathrm{M}+\mathrm{H}]^{+}$ & $\begin{array}{l}\text { Pseudomonas rubra strain PS1 } \\
\text { and SB14 } \\
\text { Zooshikella sp. } \\
\text { Streptomyces sp. }\end{array}$ & \multicolumn{2}{|l|}{$\begin{array}{l}\text { Antibacterial } \\
\text { Anticancer } \\
\text { Anti- } \\
\text { inflammatory }\end{array}$} \\
\hline \multirow{2}{*}{$\begin{array}{l}\text { Phenazine group } \\
\text { Phenazine-1- } \\
\text { carboxylic acid } \\
\text { Pyocyanin }\end{array}$} & $\mathrm{C}_{13} \mathrm{H}_{8} \mathrm{~N}_{2} \mathrm{O}_{2}$ & $252,365,354$ & $247.05[\mathrm{M}+\mathrm{Na}]^{+}$ & $\begin{array}{l}\text { Pseudomonas aeruginosa } \\
\text { strain PA31x }\end{array}$ & \multirow{2}{*}{$\begin{array}{l}\text { Antibacterial } \\
\text { Antifungal } \\
\text { Antibacterial }\end{array}$} & {$[27]$} \\
\hline & $\mathrm{C}_{13} \mathrm{H}_{11} \mathrm{~N}_{2} \mathrm{O}$ & $\begin{array}{l}201,238,318 \\
710,886\end{array}$ & $211[\mathrm{M}]^{+}$ & Pseudomonas aeruginosa & & {$[28,45]$} \\
\hline $\begin{array}{l}\text { Violacein group } \\
\text { Violacein }\end{array}$ & $\mathrm{C}_{20} \mathrm{H}_{13} \mathrm{~N}_{3} \mathrm{O}_{3}$ & 585 & $344.12[\mathrm{M}+\mathrm{H}]^{+}$ & $\begin{array}{l}\text { Janthinobacterium lividum } \\
\text { Chromobacterium violaceum } \\
\text { Pseudoalteromonas byunsanens }\end{array}$ & \multicolumn{2}{|c|}{$\begin{array}{l}\text { Antimicrobial }[29,46,47] \\
\text { Anticancer } \\
\text { is }\end{array}$} \\
\hline
\end{tabular}

between the numbers of cells from the natural environment that form colonies on agar media and the number countable by microscopic examination. Unfortunately, in marine ecosystems, only 0.01 to $0.1 \%$ of oceanic marine bacterial cells produce colonies using standard plating techniques [33]. The next challenge is achieving an adequate amount of the desired metabolites to allow identification of bacterial bioactive pigments and their bioactivity, a tedious process [34]. Another challenge in this research corresponds to genome mining. As the number of available genomes is increasing, genome mining is becoming a challenging method to identify new natural products and to validate data [35].

\section{DEVELOPMENTS AND CONSIDERATIONS}

There are a number of reasons that marine microorganisms are difficult to cultivate in the laboratory, including a lack of adequate growth conditions, low growth rates, poor development of colonies, requirement for metabolites generated by other microbes, and the presence of dormant cells [36]. Various cultivation strategies have been proposed and reviewed, such as the in situ cultivation technique that uses diffusion chambers, microbial traps, iChip (isolation chip), iTip (in situ cultivation by tip), and double encapsulation techniques [37]. Another promising new cultivation and screening strategy 
with the advantages of being high throughput, microscale, single-cell resolution, and automation potential, called the microfluidic droplet-based technique, has also been introduced [38].

Inducing stress or external stimulation has been a recent research trend and strategy to increase pigment production in the biotechnological process; for example, enhanced production of pyocyanin from Pseudomonas aeruginosa was successful with cottonseed meal [39]. The blue, yellow, white, green, incandescent lamp, red halogen, and fluorescence lamp were used for enhancing the carotenoid content, or another example using gamma radiation for an enhanced production of prodigiosin [40].

Recently, combinatorial approaches using simultaneous bioinformatics, genetics, and analytical tools have introduced new strategies for the discovery of bioactive pigments from marine bacterial isolates. As all pigments have a genetic basis, the ability to obtain and interpret genetic information have been the first step in daily based protocol for structural elucidation, a process that is increasingly available at low cost to non-specialists. Setiyono et al [18] applied analysis of the complete genome sequence of the marine bacterium Erythrobacter flavus strain KJ5 [41] to reveal the possibility of a new carotenoid present, by comparing the carotenoids composition produced by $E$. longus and E. nanhaesediminis, members of the genus Erythrobacter that have close sequence similarity and were therefore assumed to have a similar carotenoid biosynthesis pathway. Identification of sulfate attachment to the zeaxanthin carotenoid was then resolved by a tandem mass spectrometry (MS/MS) detected in negative ion mode using multiple reaction monitoring (MRM). Another example showed that BLAST analysis of antimicrobial prodiginine pigments from Pseudomonas rubra strains PS1 and SB14 to identify highly similar sequences (megablast) resulted in identification of two primary pigments, prodigiosin and cycloprodigiosin, and their derivatives [25]. Recently, with genome mining, the process of extracting information from genome sequences to detect biosynthetic pathways of bioactive natural products and their possible functional and chemical interactions has become available [35].

In combination with liquid chromatography (LC), mass spectrometry has become the gold standard for a high-throughput qualitative and quantitative profiling of natural product compounds [42], especially pigments. Other hyphenated technique such as nuclear magnetic reso- nance coupled with LC (LC-NMR) is also useful analytical platforms for detection, identification, and quantification of compounds in extracts. NMR analysis is reproducible and provides detailed structural information, although it generally profiles only major constituents, in other words, it has relatively low sensitivity. Thousands of sets of MS/MS data have been recorded and continuously developed in publicly accessible databases. Open-access knowledge bases containing tandem mass spectrometry, such as the Global Natural Products Social Molecular Networking (GNPS, https://gnps.ucsd.edu/ProteoSAFe/static/ gnps-splash.jsp) and the Natural Product Atlas (https://www.npatlas.org/joomla/), which provide a tool to explore the structure of microbial natural products, are available and have greatly enhanced the efficiency of the replication processes, leading to identification of new molecules [43]. Specifically, for the carotenoid group, the Carotenoid Database (http://carotenoiddb.jp/), at the time of writing, provides information on 1204 natural carotenoids in 722 source organisms, including their biosynthetic pathways, structures and similarity search, and some biological activities.

Acknowledgements: This work was supported by funding from the Directorate of Research and Community Services, Ministry of Research and Technology/National Research and Innovation Agency of the Republic of Indonesia under World Class Research scheme grant number 001/MACHUNG/LPPM/SP2H-LIT-MONO/IV/2021.

\section{REFERENCES}

1. Joye S, Kostka JE (2020) Microbial Genomics of the Global Ocean System. American Academy of Microbiology, Washington DC.

2. Sigwart JD, Blasiak R, Jaspars M, Jouffray J-B, Tasdemir D (2021) Unlocking the potential of marine biodiscovery. Nat Prod Rep.

3. Ramesh C, Vinithkumar NV, Kirubagaran R (2019) Marine pigmented bacteria: A prospective source of antibacterial compounds. J Nat Sci Biol Med 10, 104-113.

4. Velmurugan P, Veni CK, Ravi AV (2020) Marine bacteria is the cell factory to produce bioactive pigments: A prospective pigment source in the ocean. Front Sustain Food Syst 4, ID 589655.

5. Dias DA, Jones OAH, Beale D, Boughton BA, Benheim D, Kouremenos KA, Wolfender J, Wishart DS (2016) Current and future perspectives on the structural identification of small molecules in biological systems. Metabolites 6, ID 46.

6. Bech PK, Lysdal KL, Gram L, Bentzon-Tilia M, Strube ML (2020) Marine sediments hold an untapped po- 
tential for novel taxonomic and bioactive bacterial diversity. mSystems 5, e00782-20.

7. Hoshino T, Doi H, Uramoto GI, Wörmer L, Adhikari RR, Xiao N, Morono Y, D'Hondt S, etal (2020) Global diversity of microbial communities in marine sediment. Proc Natl Acad Sci USA 117, 27587-27597.

8. Dubilier N, Bergin C, Lott C (2008) Symbiotic diversity in marine animals: The art of harnessing chemosynthesis. Nat Rev Microbiol 6, 725-740.

9. Flórez LV, Biedermann PHW, Engl T, Kaltenpoth M (2015) Defensive symbioses of animals with prokaryotic and eukaryotic microorganisms. Nat Prod Rep 32, 879-1156.

10. Stanley JT, Castenholz RW, Colwell RR, Holt JG, Kane MD, Pace NR, Salyers AA, Tiedje JM (1997) The Microbial World: Foundation of the Biosphere. American Academy of Microbiology, Washington DC.

11. Brien PAO, Webster NS, Miller DJ, Bourne DG (2019) Host-microbe coevolution: applying evidence from model systems to complex marine invertebrate holobionts. MBio 10, e02241-18.

12. Blockley A, Elliott DR (2017) Symbiotic microbes from marine invertebrates: Driving a new era of natural product drug discovery. Diversity 9, ID 49.

13. Zhang X, Wei W, Tan R (2015) Symbionts, a promising source of bioactive natural products. Sci China Chem 58, 1097-1109.

14. Torregrosa-crespo J, Montero Z, Fuentes JL, Reig M, Carlos V, Martinez-Espinosa RM (2018) Exploring the valuable carotenoids for the large-scale production by marine microorganisms. Mar Drugs 16, ID 203.

15. Galasso C, Corinaldesi C, Sansone C (2017) Carotenoids from marine organisms: Biological functions and industrial applications. Antioxidants 6, ID 96.

16. Kallscheuer N, Moreira C, Airs R, Llewellyn CA, Wiegand S, Jogler C, Lage OM (2019) Pink- and orangepigmented Planctomycetes produce saproxanthintype carotenoids including a rare C45 carotenoid. Environ Microbiol Rep 11, 741-748.

17. Vila E, Hornero-Méndez D, Azziz G, Lareo C, Saravia V (2019) Carotenoids from heterotrophic bacteria isolated from Fildes Peninsula, King George Island, Antarctica. Biotechnol Rep 21, e00306.

18. Setiyono E, Heriyanto, Pringgenies D, Shioi Y, Kanesaki Y, Awai K, Brotosudarmo THP (2019) Sulfurcontaining carotenoids from a marine coral symbiont Erythrobacter flavus strain KJ5. Mar Drugs 17, ID 349.

19. Asker D (2017) Isolation and characterization of a novel, highly selective astaxanthin-producing marine bacterium. J Agric Food Chem 65, 9101-9109.

20. Liu H, Zhang C, Zhang X, Tan K, Zhang H, Cheng D, Ye T, Li S, et al (2020) A novel carotenoids-producing marine bacterium from noble scallop Chlamys nobilis and antioxidant activities of its carotenoid compositions. Food Chem 320, ID 126629.

21. Brotosudarmo THP, Limantara L, Setiyono E,
Heriyanto (2020) Structures of astaxanthin and their consequences for therapeutic application. Int $J$ Food Sci 2020, 14-17.

22. Tawfike A, Attia EZ, Desoukey SY, Hajjar D, Makki AA, Schupp PJ, Edrada-Ebel RA, Abdelmohsen UR (2019) New bioactive metabolites from the elicited marine sponge-derived bacterium Actinokineospora spheciospongiae sp. nov. AMB Express 9, ID 12.

23. Kim MC, Cullum R, Hebishy AMS, Mohamed HA, Faraag AHI, Salah NM, Abdelfattah MS, Fenical W (2020) Mersaquinone, a new tetracene derivative from the marine-derived Streptomyces sp. EG1 exhibiting activity against methicillin-resistant Staphylococcus aureus (MRSA). Antibiotics 9, ID 252.

24. Liang Y, Xie X, Chen L, Yan S, Ye X, Anjum K, Huang $\mathrm{H}$, Lian X, et al (2016) Bioactive polycyclic quinones from marine Streptomyces sp. 182SMLY. Mar Drugs 14, ID 10.

25. Setiyono E, Adhiwibawa MAS, Indrawati R, Prihastyanti MUU, Shioi Y, Brotosudarmo THP (2020) An Indonesian marine bacterium, Pseudoalteromonas rubra, produces antimicrobial prodiginine pigments. ACS Omega 5, 4626-4635.

26. Ramesh C, Vinithkumar NV, Kirubagaran R, Venil CK, Dufoseé L (2020) Applications of prodigiosin extracted from marine red pigmented bacteria Zooshikella sp. and Actinomycete Streptomyces sp. Microorganisms 8, ID 556.

27. Zhang L, Tian X, Kuang S, Liu G, Zhang C, Sun C (2017) Antagonistic activity and mode of action of phenazine-1-carboxylic acid, produced by marine bacterium Pseudomonas aeruginosa PA31x, against Vibrio anguillarum in vitro and in a zebrafish in vivo model. Front Microbiol 8, ID 289.

28. DeBritto S, Gajbar TD, Satapute P, Sundaram L, Lakshmikantha RY, Jogaiah S, Ito S (2020) Isolation and characterization of nutrient dependent pyocyanin from Pseudomonas aeruginosa and its dye and agrochemical properties. Sci Rep 10, ID 1542.

29. Wu YH, Cheng $\mathrm{H}, \mathrm{Xu} \mathrm{L}$, Jin XB, Wang CS, Xu XW (2017) Physiological and genomic features of a novel violacein-producing bacterium isolated from surface seawater. PLoS One 12, e0179997.

30. Jiao JY, Liu L, Hua ZS, Fang BZ, Zhou EM, Salam N, Hedlund BP, Li WJ (2021) Microbial dark matter coming to light: Challenges and opportunities. Natl Sci Rev 8, ID nwaa280.

31. Sun W, Wu W, Liu X, Zaleta-Pinet DA, Clark BR (2019) Bioactive compounds isolated from marinederived microbes in China: 2009-2018. Mar Drugs 17, ID 339.

32. Staley JT, Konopka A (1985) Microorganisms in aquatic and terrestrial habitats. Annu Rev Microbiol 39, 321-346.

33. Connon SA, Giovannoni SJ (2002) High-throughput methods for culturing microorganisms in very-lownutrient media yield diverse new marine isolates. 
Appl Environ Microbiol 68, 3878-3885.

34. Joint I, Mühling M, Querellou J (2010) Culturing marine bacteria: An essential prerequisite for biodiscovery: Minireview. Microb Biotechnol 3, 564-575.

35. Albarano L, Esposito R, Ruocco N, Costantini M (2020) Genome mining as new challenge in natural products discovery. Mar Drugs 18, ID 199.

36. Overmann J, Lepleux C (2016) Marine bacteria and archaea: Diversity, adaptations, and culturability. In: Stal LJ, Cretoiu MS (eds) The Marine Microbiome: An Untapped Source of Biodiversity and Biotechnological Potential, Springer International Publishing, Switzerland, pp 21-56.

37. Wang F, Li M, Huang L, Zhang XH (2021) Cultivation of uncultured marine microorganisms. Mar Life Sci Technol 3, 117-120.

38. Hu B, Xu B, Yun J, Wang J, Xie B, Li C, Yu Y, Lan Y, et al (2020) High-throughput single-cell cultivation reveals the underexplored rare biosphere in deepsea sediments along the Southwest Indian Ridge. Lab Chip 20, 363-372.

39. El-Fouly MZ, Sharaf AM, Shahin AAM, El-Bialy HA, Omara AMA (2015) Biosynthesis of pyocyanin pigment by Pseudomonas aeruginosa. $J$ Radiat Res Appl Sci 8, 36-48.

40. Chatragadda R, Dufossé L (2021) Ecological and biotechnological aspects of pigmented microbes: A way forward in development of food and pharmaceutical grade pigments. Microorganisms 9, ID 637.

41. Kanesaki Y, Setiyono E, Pringgenies D, Moriuchi
R, Brotosudarmo THP, Awai K (2019) Complete genome sequence of the marine bacterium Erythrobacter flavus strain KJ5. Microbiol Resour Announc 8, e00140-19.

42. Atanasov AG, Zotchev SB, Dirsch VM, Orhan IE, Banach M, Rollinger JM, Barreca D, Weckwerth W, et al (2021) Natural products in drug discovery: Advances and opportunities. Nat Rev Drug Discov 20, 200-216.

43. Rotter A, Barbier M, Bertoni F, Bones AM, Cancela ML, Carlsson J, Carvalho MF, Cegłowska M, et al (2021) The essentials of marine biotechnology. Front Mar Sci 8, ID 629629.

44. Ghareeb MA, Tammam MA, El-Demerdash A, Atanasov AG (2020) Insights about clinically approved and preclinically investigated marine natural products. Curr Res Biotechnol 2, 88-102.

45. Li JL, Yang N, Huang L, Chen D, Zhao Y, Tang MM, Fan H, Bao X (2018) Pyocyanin inhibits Chlamydia infection by disabling infectivity of the elementary body and disrupting intracellular growth. Antimicrob Agents Chemother 62, e02260-17.

46. Arif S, Batool A, Khalid N, Ahmed I, Janjua HA (2017) Comparative analysis of stability and biological activities of violacein and starch capped silver nanoparticles. RCS Adv 7, 4468-4478.

47. Choi SY, Lim S, Yoon K, Lee JI, Mitchell RJ (2021) Biotechnological activities and applications of bacterial pigments violacein and prodigiosin. J Biol Eng 15, ID 10. 